\title{
POSTURAL ASSESSMENT OF GIRLS BETWEEN 7 AND 10 YEARS OF AGE
}

\author{
Patrícia Jundi Penha, Sílvia Maria Amado João, Raquel Aparecida Casarotto, \\ Carlos Junichiro Amino and Daniela Caielli Penteado
}

PENHA PJ et al. Postural assessment of girls between 7 and 10 years of age. CLINICS 60(1):9-16, 2005.

Postural alterations are often found in children and teenagers. In this stage of development, the posture undergoes many adjustments and adaptations due to changes of the body and to demanding psychosocial factors.

PURPOSE: To identify which postural alterations occur most often in students between 7 and 10 years of age, to identify preventive measures, and to provide information to parents and teachers about the problem of bad posture.

METHODS: Thirty three girls in each of 4 age groups between 7 and 10 years of age were assessed, resulting in a sample of 132 subjects. Photos of each girl in the sagittal and frontal planes were examined for postural deviations.

RESULTS: The main postural deviations found were knock-knee, medial rotation of the hip, antepulsion, pelvic anteversion, knee hyperextension, lumbar hyperlordosis, valgus ankle, imbalanced shoulders, lateral pelvic inclination, scoliosis, trunk rotation, thoracic hyperkyphosis, winged scapula, shoulder protraction, abducted scapula, medial rotation of shoulders, and head tilt.

CONCLUSION: High incidences of postural alterations occur in children of school age. Some of these reflect normal postural development, and get corrected during the child's growth. On the other hand, some alterations are asymmetries that can be caused by daily demands on the body and can result in negative impacts on the quality of life during childhood and adulthood. We emphasize the importance of providing information to parents and teachers about the problem of bad posture.

KEYWORDS: Posture. Physical therapy, Students. Posture assessment.

Posture is often defined as the relative arrangement of body parts. Good posture is the state of muscular and skeletal balance that protects the body structures against injury or progressive deformity independent of the attitude (erect, lying, stooping, bent) in which these structures are working or resting. Under such conditions, muscles work more efficiently, and ideal positions are allocated to the thoracic and abdominal organs. ${ }^{1,2}$

Bad posture is a defective relationship between the several parts of the body that produces greater tension in the

From the Department of Physiotherapy, Audiology, and Occupational Therapy and the Pediatric Department, Hospital das Clínicas, Faculty of Medicine, University of São Paulo - São Paulo/SP, Brazil.

E-mail: smaj@usp.br

Received for publication on March 26, 2004.

Accepted for publication on June 28, 2004. supportive structures, and where a less efficient body balance on the supportive base occurs. ${ }^{1,2}$

There are intrinsic and extrinsic factors that can influence the subject's posture, such as heredity, the environment or physical conditions in which the subject lives, socioeconomic level, emotional factors, and physiologic alterations due to human growth and development.

The prepuberal phase and puberty are periods of life during which the posture undergoes many adjustments and adaptations due to changes in the body and to demanding psychosocial factors. Between 7 and 12 years of age, a child's posture undergoes a big transformation to reach a compatible balance with the new corporal proportions. Bankoff and Brighetti ${ }^{3}$ discuss the question of the formation of the body schema in childhood through the motor experiences during this period and how an imbalance in 
the tonic-postural structure can last for the entire adolescence and adult life.

Pires et al. ${ }^{4}$ report that improper postures adopted by children at home and school cause an imbalance in the body musculature, resulting in postural alterations, and they assert that vigilance by parents and teachers is very important for the timely correction of postural deviations so as to avoid permanent deformities.

The identification of the postural habits adopted by children and the postural alterations that often result is important (i) for prevention, ${ }^{2,5}$ (ii) to encourage a healthier posture for children, and (iii) to prevent resulting painful syndromes.

Therefore, the main objectives of this study were to identify which postural alterations occur most frequently in students between 7 to 10 years of age and to provide information to parents and teachers about the problem of bad posture.

\section{METHODS}

\section{Subject demographics}

This project assessed 33 girls in each of 4 age groups between 7 and 10 years of age (Table1), resulting a sample of 132 girls. The children were selected randomly, and the exclusion criteria were students with neuromuscular and/ or traumatic pathologies.

Table 1 - Definition of children age groups as employed in this report.

\begin{tabular}{ll}
\hline Age & $\begin{array}{l}\text { Age Group } \\
\text { Classification }\end{array}$ \\
\hline 6 years and 9 months to 7 years and 8 months & 7 years old \\
7 years and 9 months to 8 years and 8 months & 8 years old \\
8 years and 9 months to 9 years and 8 months & 9 years old \\
9 years and 9 months to 10 years and 8 months & 10 years old \\
\hline
\end{tabular}

\section{Procedures}

The data were collected at the Escola Estadual de Primeiro Grau "Clorinda Danti" in São Paulo. The students' parents were notified through a letter with information about the postural examination, and signed the informed consent. The project was approved by Ethics Committee of Hospital das Clínicas, Faculty of Medicine, University of São Paulo.

After the postural assessment, the students with significant postural alterations were referred to the physiotherapy team. A class entitled Posture Day for parents, students, and school employees, but primarily for teachers, was given to provide information about the problem of bad posture.
A simetrógrafo ${ }^{\circledR}$ was used for the postural assessment. The reference points of Kendall et al. ${ }^{1}$ were used as normal parameters. Each student had the following bone references marked as follows: lateral malleoli; head of the fibulae; major trochanter of the femur; anterior superior and posterior superior iliac spines; coracoid processus; cervical (C5 and C7), thoracic (T2 and T7), lumbar (L1 and L5), and sacral (S1) spinous processus; and inferior angle of the scapula.

The postural assessment was made through photos of the students made in the orthostatic posture in the sagittal and frontal planes. In the sagittal plane, the following alterations were analyzed: opened and closed tibiotarsal angle, antepulsion, retropulsion, knee hyperextension and semiflexion, pelvic anteversion and retroversion, lumbar hyperlordosis, lumbar rectification, thoracic hyperkyphosis, thoracic rectification, trunk rotation, protraction and medial rotation of the shoulder, cervical hyperlordosis, cervical rectification, and head protraction. Additionally, in the frontal plane, the following were analyzed: valgus hallux; abducted forefoot; knock-knee and bowleg; medial and lateral rotation of the hip; lateral pelvic inclination; shoulder imbalance; head tilt; valgus and varus ankle; and winged, abducted, and adducted scapula. A digital camera (SONY MVC-FD200/FD Mavica) was positioned at a standardized distance of $2.56 \mathrm{~m}$ from the simetrógrafo and at a height of $78.5 \mathrm{~cm}$. The subjects wore bathing clothes and/or shorts and top.

The spine flexibility tests were assessed through of the tests of Stibor $^{6}$ and Schober. ${ }^{6}$ Tests to determine the difference of the length of the lower limbs were performed to differentiate real and apparent discrepancies. ${ }^{7,8}$

The collected data were statistically described (average and percentage).

\section{RESULTS}

The main postural deviations found in this study were: knock-knee (64\% in the 7 year-old group, $58 \%$ in the 8 and 9 year-old groups, and $45 \%$ in the 10 year-old group), medial rotation of the hip $(70 \%-7,55 \%-8,73 \%-9$, and $76 \%-$ 10 ), antepulsion $(64 \%-7,45 \%-8,42 \%-9$, and $48 \%-10)$, pelvic anteversion $(73 \%-7,58 \%-8,67 \%-9$, and 64\%-10), knee hyperextension $(67 \%-7,64 \%-8,55 \%-9$, and 48\%-10), lumbar hyperlordosis $(55 \%-7,61 \%-8,52 \%-9$, and 61\%-10), valgus ankle (55\%-7, 76\%-8, 67\%-9 and 10), shoulder imbalance $(73 \%-7,82 \%-8,58 \%-9$, and 70\%-10), lateral pelvic inclination $(58 \%-7,76 \%-8,48 \%-9$, and 61\%-10), scoliosis $(36 \%-7,45 \%-8,52 \%-9$, and $48 \%-10)$, trunk rotation (82\%-7, 79\%-8, 91\%-9 and 10), thoracic hyperkyphosis (21\%-7, 27\%-8, 45\%-9, and 42\%-10), winged scapula (70\%-7 and $8,55 \%-9$, and 64\%-10), shoulder protraction 
Table 2 - Primary postural deviations in 133 girls aged 7 to 10 years of age.

\begin{tabular}{|c|c|c|c|c|}
\hline Postural variation & 7 year-olds $(n=33)$ & 8 year-olds $(n=33)$ & 9 year-olds $(n=33)$ & 10 year-olds $(n=33)$ \\
\hline knock-knee & $64 \%$ & $58 \%$ & $58 \%$ & $45 \%$ \\
\hline medial rotation of the hip & $70 \%$ & $55 \%$ & $73 \%$ & $76 \%$ \\
\hline Antepulsion & $64 \%$ & $45 \%$ & $42 \%$ & $48 \%$ \\
\hline pelvic anteversion & $73 \%$ & $58 \%$ & $67 \%$ & $64 \%$ \\
\hline knee hyperextension & $67 \%$ & $64 \%$ & $55 \%$ & $48 \%$ \\
\hline lumbar hyperlordosis & $55 \%$ & $61 \%$ & $52 \%$ & $61 \%$ \\
\hline valgus ankle & $55 \%$ & $76 \%$ & $67 \%$ & $67 \%$ \\
\hline shoulder imbalance & $73 \%$ & $82 \%$ & $58 \%$ & $70 \%$ \\
\hline lateral pelvic inclination & $58 \%$ & $76 \%$ & $48 \%$ & $61 \%$ \\
\hline Scoliosis & $36 \%$ & $45 \%$ & $52 \%$ & $48 \%$ \\
\hline trunk rotation & $82 \%$ & $79 \%$ & $91 \%$ & $91 \%$ \\
\hline thoracic hyperkyphosis & $21 \%$ & $27 \%$ & $45 \%$ & $42 \%$ \\
\hline winged scapula & $70 \%$ & $70 \%$ & $55 \%$ & $64 \%$ \\
\hline shoulder protraction & $76 \%$ & $58 \%$ & $79 \%$ & $82 \%$ \\
\hline abducted scapula & $55 \%$ & $48 \%$ & $55 \%$ & $55 \%$ \\
\hline medial rotation of shoulders & $55 \%$ & $55 \%$ & $67 \%$ & $67 \%$ \\
\hline head tilt & $58 \%$ & $64 \%$ & $45 \%$ & $76 \%$ \\
\hline
\end{tabular}

(76\%-7, 58\%-8, 79\%-9, and 82\%-10), abducted scapula (55\%-7, 9 and 10, and 48\%-8), medial rotation of shoulders (55\%-7 and 8, and 67\%-9 and 10), and head tilt (58\%$7,64 \%-8,45 \%-9$, and 76\%-10). The findings regarding the main postural variations are listed in Table 2 .

Figures 1, 2, and 3 compare the main postural deviations of the lower limbs, trunk, and upper limbs among age groups. For these figures, the results selected were those that had an incidence larger than $50 \%$ or that varied among the age groups;.

The average of Stibor's indexes ${ }^{6}$ approximated the normal value (the adult normal value is $10 \mathrm{~cm}$ ) described for adults in all of the age groups, as follows: $9.3 \mathrm{~cm}$ in the 7- and 8-year-old groups, $10 \mathrm{~cm}$ in the 9-year-old group and $9.7 \mathrm{~cm}$ in the 10-year-old group. However, the average of Schober's indexes ${ }^{6}$ was larger than the normal value described for adults (the adult normal value is $5 \mathrm{~cm}$ ), as follows: $7.4 \mathrm{~cm}$ in the 7 and 9 year-olds and $7 \mathrm{~cm}$ in the 8 and 10 year-olds.

The incidence of real discrepancy in the lower limb length (greater than $1.5 \mathrm{~cm}^{8}$ ) was $12 \%$ of the 7 year-olds, $9.1 \%$ of the 8 and 10 year-olds, and $0 \%$ of the 9 year-olds. Regarding the apparent discrepancy test (greater than 1.5 $\mathrm{cm}^{8}$ ), the incidence was $6.1 \%$ of the 7 year-olds, $0 \%$ of the 8 and 9 year-olds, and $3.0 \%$ of the 10 year-olds.

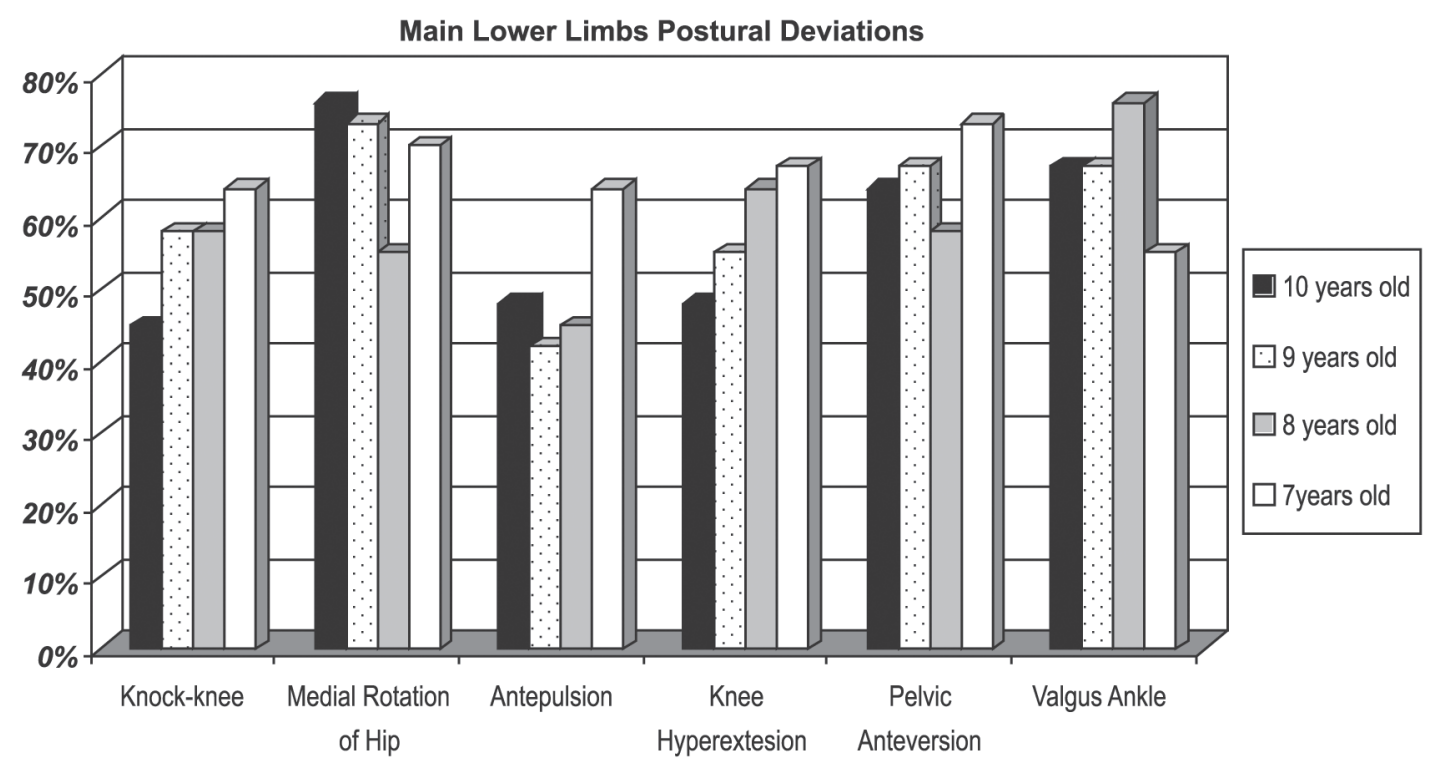

Figure 1 - Comparison among the main postural deviations of the lower limbs. 
Main Trunk Postural Deviations

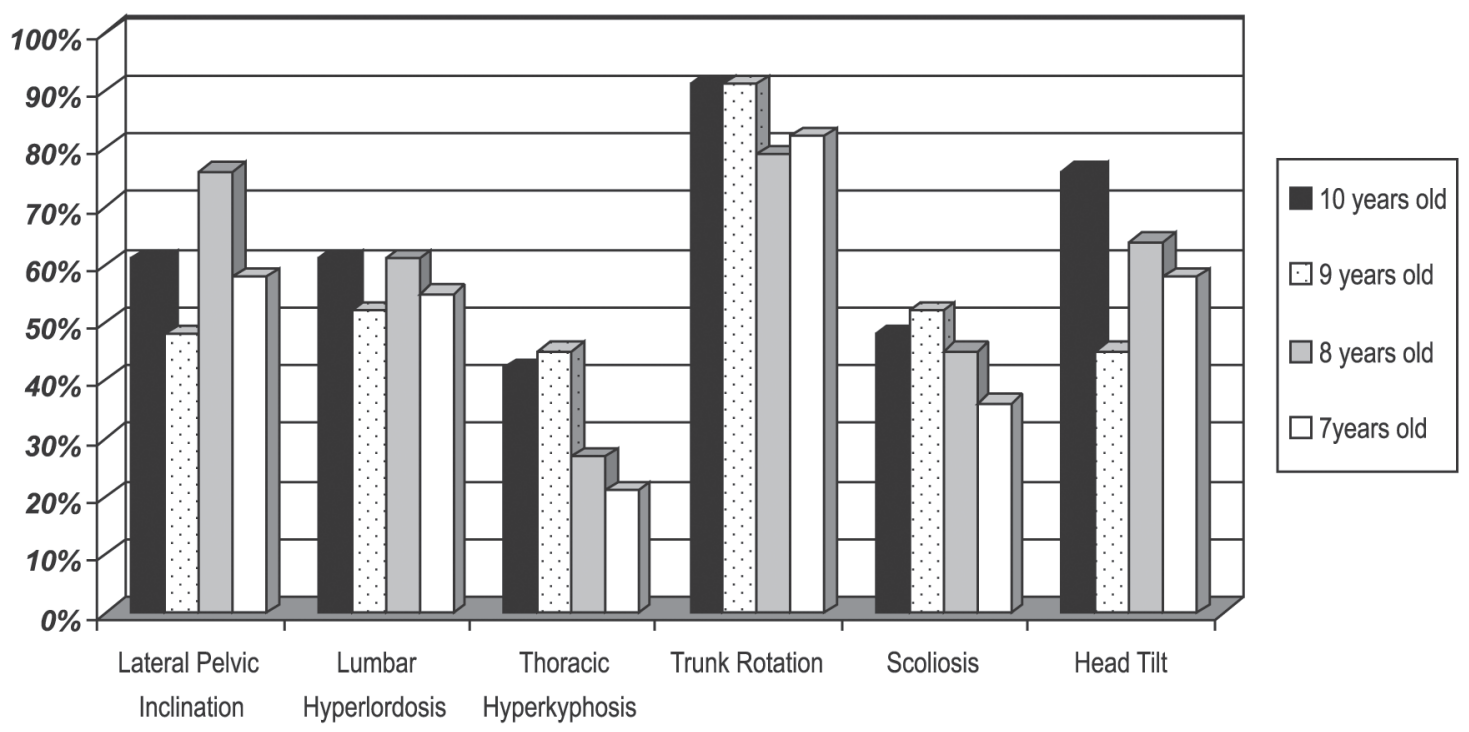

Figure 2 - Comparison among the postural deviations of the main trunk.

Main Upper Limbs Postural Deviations

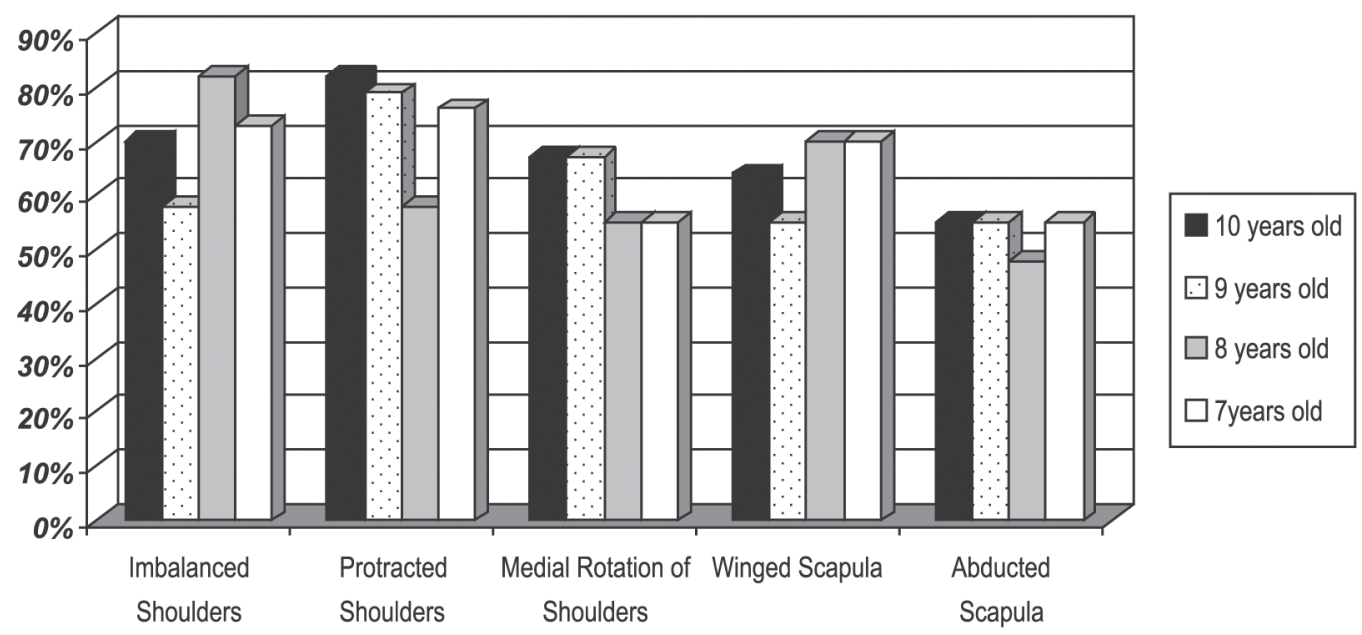

Figure 3 - Comparison among the main postural deviations of the upper limbs.

\section{DISCUSSION}

A child is not supposed to have an adult's standard alignment, because greater mobility and flexibility occur during development. The large range of motion in the child may cause temporary deviations in the alignment that would be considered abnormal in adults. At the same time, this flexibility in a certain way protects against fixed postural malalignment.

In this study, the frequency of knock-knee was greater in 7 year-olds $(64 \%)$, which could be explained by the normal postural development of the lower limbs; knock-knee is physiologic among 3 to 7 year-olds. ${ }^{9,10}$ The physiologic knock-knee in children can also occur to medially change the center of gravity ${ }^{8}$ and, thus, to improve the balance. Pinho and Duarte ${ }^{11}$ observed a higher frequency of knockknee in females in the age groups of $7(30 \%)$ and 8 years of age $(30 \%)$, in a total of 111 girls assessed. These results differ from those obtained by Rosa Neto, ${ }^{12}$ in which - out of a sample of 791 students of both sex between 7 and 12 years of age $-11.6 \%$ had knock-knee, and $4.9 \%$ were presented by girls.

The medial rotation of the hip is a very significant postural alteration. Ishida and Kuwajima ${ }^{13}$ comment about the influence of the femoral collum anteversion angle on the child's hip rotation: the larger the femoral collum an- 
teversion, the greater the medial rotation of the range of motion of the hip; the lateral rotation range of motion is limited to around $10^{\circ}$ until 12 years of age.

The occurrence of the antepulsion was larger in 7 yearolds (64\%). This fact can be related to the attempt to improve the anteroposterior balance in younger children, with the anterior displacement of the gravity center. Pinho and Duarte ${ }^{11}$ report in their study a considerable index of trunkahead projection (antepulsion), but reasons for antepulsion have not been reported.

Pelvic anteversion, knee hyperextension, and the lumbar hyperlordosis are postural deviations that have as a common cause a deficit of abdominal restraint. ${ }^{11,12,14}$ Abdominal protrusion relates directly to the mentioned alterations in an attempt to correct the anteroposterior balance that is compromised. The muscles of the anterolateral abdominal wall have the postural function of abdominal restraint - stabilizing the lumbar spine when these muscles are in balance with the lumbar paravertebral - and of pelvic retroversion. ${ }^{15}$ During the child's development, the abdominal work becomes more effective, which occurs mainly between 10 and 12 years of age, with the decrease of the waist line and of the abdominal protrusion. ${ }^{1}$ This fact may be one of the reasons for the progressive decrease of the pelvic anteversion, lumbar hyperlordosis, and knee hyperextension during to the child's development. These deviations decreased with increasing age for all the age groups in this study, In his sample, Rosa Neto ${ }^{12}$ obtained results that indicated a lower frequency of pelvic anteversion: $15.2 \%$ without distinction among the ages groups. Pinho and Duarte $^{11}$ found a similar behavior in the females with respect to lumbar hyperlordosis $78 \%$ at 7 years, $67 \%$ at 8 , $55 \%$ at 9 , and $45 \%$ at 10 years of age as well as a lower incidence of knee hyperextension $4 \%$ at 7 years, $10 \%$ at 8 , and $7 \%$ at 9 and 10 year of age. According to Asher, ${ }^{16}$ knee hyperextension may very often occur in children between 6 and 11 years of age as a mechanism for anteroposterior weight distribution.

Valgus ankle is related to increased weight loading on the medial aspect of the foot, tending to a flatfoot. Between 7 and 10 years of age, the longitudinal medial arch is already formed, which removes the possibility of a physiologic and rapid malalignment. Other causes might be muscular weakness or lack of coordination of the ankle stabilizer muscle and of the intrinsic foot muscles, in addition to the wearing of improper shoes. Kendall et al. ${ }^{1}$ related the appearance of foot pronation to medial rotation of hip and knee hyperextension.

Shoulder imbalance may be related to the subject's side dominance. ${ }^{1}$ Raine and Tworney ${ }^{17}$ discussed this relationship, stating that the lower shoulder would correspond to the dominant side. Nevertheless, they point out that this difference is very small and may not be discerned clinically. They do note that they found the right shoulder to be more frequently lower by one degree than the left one. This postural alteration may also be associated with muscular asymmetry, lateral spine deviation, ${ }^{18}$ or to lateral pelvic inclination, being harmful when it is accentuated.

During the school years, the child's posture is subjected to many influences, and some alterations may appear due to improper postural habits. ${ }^{19}$ The influence of transportation of school materials on the occurrence of the postural deviations (eg shoulder imbalance and scoliosis) in students was investigated by Rebellato et al.,$^{20}$ who assessed the way of carrying the backpack, the weight of school materials, the average forces on the muscular groups responsible for the maintenance of the transported load, and the postural alterations observed during the use of the backpack.

The slight spine deviation towards the contralateral higher hip can appear as early as in 7 and 8 year-olds, with a compensating lower shoulder on the higher hip side. ${ }^{1}$

Scoliosis was observed in $36 \%$ of the 7 year-olds, $45 \%$ of the 8 year-olds, $52 \%$ of the 9 year-olds, and $48 \%$ of the 10 year-olds. Pinho and Duarte ${ }^{11}$ found lower scoliosis incidences in girls, with $30 \%$ at 7 years; $17 \%$ at 8 years; $31 \%$ at 9 years, and $21 \%$ at 10 years of age. Bertoldi et al. ${ }^{14}$ found the frequency of scoliosis to be $23.8 \%$ among students between 7 to 12 years of age. Mota ${ }^{21}$ analyzed the incidence of scoliosis in a sample of 102 students (between 11 and 16 years of age) and found it to be higher among females, with $12.5 \%$ of girls presenting structural scoliosis and $25 \%$ a functional variant.

A difference in the leg length greater than or equal to $1.5 \mathrm{~cm}$ is regarded as a significant alteration that may cause a postural deviation such as scoliosis. ${ }^{8}$ In our study, we found only a small incidence of significant lower limb length difference, both regarding real length as well as an apparent difference.

Another notable postural alteration presented in this study was the increase of the thoracic hyperkyphosis. This increase is usually related to periods of rapid growth, ${ }^{22}$ and it can occur in subjects during the growth spurt of puberty, which is very important in girls, since there is a tendency to adopt this posture as a manner of hiding breast development. Since puberty can occur earlier for some people, perhaps this is the reason why increased thoracic hyperkyphosis was found in our study. Pinho and Duarte ${ }^{11}$ found similar values of thoracic hyperkyphosis among the ages (9\% at 7 years, $17 \%$ at 8 , and $10 \%$ at 9 and 10 years of age). Some authors have related scapular instability to the occurrence of thoracic hyperkyphosis., ${ }^{3,23}$

Alterations in the scapular girdle and shoulder appear 
to be correlated, as shown in several articles ${ }^{3,11,14}$ in which the terms winged scapula, shoulder protraction, and abducted scapula are used as synonyms. Winged scapula has been observed in significant numbers at all ages. It is common during the childhood, according to Kendall et al. ${ }^{1}$ and Gross, ${ }^{24}$ due to poor scapulothoracic fixation. Ferronato et al. ${ }^{23}$ described separately sagittal scapula obliquity and the increased distance between the medial scapula side and the thoracic spine (abduction), observing a positive correlation between them.

As with winged scapula, shoulder protraction occurred in a great majority of children in all age groups of this study. Pinho and Duarte ${ }^{11}$ reported the frequency of shoulder protraction among ages as follows: $17 \%$ at 7 years, $47 \%$ at 8 , $34 \%$ at 9 , and $55 \%$ at 10 years of age. Bertoldi et al. ${ }^{14}$ found a frequency of $54.8 \%$ in subjects of both sexes between 7 and 12 years of age. Pini ${ }^{25}$ says that the high incidence of shoulder protraction is normal in the child-development process, and it starts to decrease from 10 years of age on. According to Tanaka and Farah, ${ }^{15}$ shoulder protraction is mechanically associated with the scapular abduction; it can be also related to its lateral rotation and to the medial rotation of the shoulders, which occurs because of the predominant action of serratus anterior and major pectoral muscles over the rhomboid and trapezius muscles.

Medial rotation of the shoulders is highly related to scapular abduction, as this study shows. This occurs because, according to Palastanga et al. ${ }^{26}$ "the pectoral girdle movements are used to increase the range of motion of the shoulder joint, mainly because they change the relative position of glenoid fossa related to the thoracic wall." Tanaka and Farah ${ }^{15}$ also assert that shoulder protraction facilitates the action of the medial rotator muscles of the shoulder because the upper limbs hang in an open kinetics chain.

The Stibor's and Schober's indexes ${ }^{6}$ measure, respectively, the flexibility of the entire spine and of the lumbar spine. In this study, only the Schober's index ${ }^{6}$ was greater in all the age groups, which could indicate a higher flexibility of the lumbar spine in children. Kendall et al. ${ }^{1}$ report on the extreme lumbar flexibility in small children (4 to 10 years old) and assert that this behavior is modified from 11 years of age on, when the legs become proportionally longer than the trunk.

In summary, the data from this study show that the posture assumed by the child is modified during the dynamic process of the neuropsychomotor development. It has been noted several times that a disarrangement of posture can be physiologic during a certain phase of musculoskeletal system development, but later in development, it can be improper and cause harmful overloads to the body.

\section{CONCLUSION}

This study showed high incidences of postural alterations in school-aged children. Some of the postural alterations described, such as knock-knee, medial rotation of hip, and lumbar hyperlordosis, reflect normal postural development, and they are corrected naturally during the children's growth. Other alterations, such as the scoliosis, are asymmetries that can be caused by daily demands on the body, including sitting in inadequately designed school furniture, practicing sedentary behavior, carrying heavy backpacks, and wearing improper shoes.

However, there is little information characterizing postural standards for children. There are only studies on some of the postural alterations, such as knock-knee.

Therefore, in this study we not only describe postural alterations occurring most often in children between 7 and 10 years of age, but also emphasize the importance of providing information to parents and teachers about the problem of bad posture and its possible negative consequences, including pain and functional impairment, to the quality of life both in childhood and adulthood.

\section{RESUMO}

PENHA PJ e col. Avaliação postural em meninas de 7 a 10 anos. CLINICS 60(1):9-16, 2005.

Alterações posturais são freqüentemente encontradas em crianças e adolescentes. Nessa fase, a postura sofre uma série de ajustes e adaptações às mudanças no próprio corpo e à demanda psicossocial que lhe é apresentada, ocorrendo uma grande transformação na busca de um equilíbrio compatível com suas condições.

OBJETIVO: Identificar quais as alterações posturais mais freqüentes em escolares, de 7 a 10 anos, com intuito de fundamentar medidas preventivas e, secundariamente, 
alertar pais e professores para o problema da má postura.

MÉTODOS: Foram avaliadas 33 meninas para cada idade entre 7 a 10 anos, totalizando uma amostra de 132 sujeitos. Cada estudante foi observado através de fotos nos planos frontal e sagital.

RESULTADOS: Os principais desvios posturais encontrados foram: joelho valgo, rotação medial de quadril, antepulsão, anteversão pélvica, hiperextensão de joelho, hiperlordose lombar, tornozelo valgo, desnível de ombro, inclinação pélvica lateral, escoliose, rotação de tronco, hipercifose torácica, escápula alada, protração de ombros, abdução escapular, rotação medial de ombro e inclinação de cabeça.
CONCLUSÃO: Este estudo alcançou seu objetivo de descrever os padrões posturais mais freqüentes entre meninas de 07 a 10 anos. Algumas das alterações posturais descritas são próprias do desenvolvimento postural normal da criança e tendem a serem incorporadas com seu crescimento - como o valgismo de joelho, a rotação medial de quadril e a hiperlordose lombar. Outras, no entanto, caracterizam assimetrias que podem ser geradas por demandas diárias como, por exemplo, a escoliose.

UNITERMOS: Postura. Fisioterapia. Estudantes. Avaliação postural.

\section{REFERENCES}

1. Kendall FP, McCreary EK, Provance PG. Músculos provas e funções. São Paulo: Editora Manole; 1995.

2. Knoplich J. Enfermidades da Coluna Vertebral. $2^{a}$ ed. São Paulo: Panamed Editorial; 1986

3. Bankoff ADP, Brighetti V. Levantamento da Incidência de Cifose Postural e Ombros Caídos em Alunos de $1^{\mathrm{a}}$ à $4^{\mathrm{a}}$ séries escolar. Revista Brasileira de Ciências do Esporte 1986;7(3): 93-7.

4. Pires AC, Silva PCF, Silva PMP, Medeiros SM, Gasparin V. Prevenção fisioterápica de escoliose em crianças da primeira série do $1^{\circ}$ grau. Fisioterapia em movimento 1990;2(2):45-80.

5. Pereira APB, Sousa LAP, Sampaio RF. Back School: Um Artigo de Revisão. Rev Bras Fisioter 2001;5(1):1-8

6. Marques AP. Manual de Goniometria. $2^{\mathrm{a}}$ ed. São Paulo: Editora Manole; 2003. p. 74-75.

7. Hoppenfeld S. Propedêutica Ortopédica: coluna e extremidades São Paulo: Editora Atheneu; 1999. p. 172-3.

8. Magee DJ. Avaliação Musculoesquelética. $3^{a}$ ed. São Paulo: Editora Manole; 2002.

9. Salenius P, Vanka E. The development of tibiofemoral angle in children. J Bone Jt Surg 1975;57(A):259-61.

10. Tolo VT. The lower extremity. In: Morrisy RT, Weinstein SL. Pediatric Orthopaedics. Philadelphia: Lippincott-Raven Publishers; 1996. p. 1047-81.

11. Pinho RA, Duarte MFS. Análise postural em escolares de Florianópolis - SC. Rev. Brasileira de Atividade Física e Saúde $1995 ; 1(2): 49-58$

12. Rosa Neto FN. Avaliação postural em escolares de primeira à quarta série do primeiro grau. Rev. Brasileira de Ciência e Movimento $1991 ; 5(2): 07-10$
13. Ishida A, Kuwajima SS. Desenvolvimento Postural dos Membros Inferiores na Criança. In: Barros TE, Lech O. Exame Físico em Ortopedia. São Paulo: Editora Sarvier; 2001. p. 301-8.

14. Bertoldi LF, Bianchi PC, Borges NP, Carrara E, Carvalho SM, Castellani TM, et al. Avaliação e orientação postural em escolares de 7-12 anos do Colégio Estadual Jardim Piza-Roseira. (Disponível http://www.ccs.br/olhomagico/peepin98/ Gim16.html -Dezembro 2002)

15. Tanaka C, Farah EA. Anatomia Funcional das Cadeias Musculares. São Paulo: Editora Ícone; 1997.

16. Asher C. Variações de Postura na Criança. São Paulo: Editora Manole; 1976, Apud Bankoff ADP, Brighetti V. Levantamento da Incidência de Cifose Postural e Ombros Caídos em Alunos de $1^{\mathrm{a}}$ à $4^{\mathrm{a}}$ séries escolar. Revista Brasileira de Ciências do Esporte 1986; 7(3): 93-7.

17. Raine S, Twomey LT. Head and Shoulder Posture Variations in 160 Asymptomatic Women and Men. Arch Phys Med Rehabil 1997;78:1215-23.

18. Fornasari CA. Repensando a Clássica Avaliação Postural. Fisioterapia em Movimento 1994;6(2):40-8

19. Casarotto RA, Liberti EA. Dados antropométricos de pré-escolares da cidade de São Paulo. Rev. Fisioterapia da USP 1994 jul/dez; $1(1)$.

20. Rebelatto JR, Caldas MAJ, Vitta A. Influência do transporte do material escolar sobre a ocorrência de desvios posturais em estudantes. Rev. Brasileira de Ortopedia 1991;26(11/12):40310 .

21. Mota JS. A postura como factor de observação na escola. Rev. Brasileira de Ciência e Movimento 1991;5(2):36-40.

22. Warner WC. Kiphosis. In: Morrisy RT, Weinstein SL. Pediatric Orthopaedics. Philadelphia: Lippincott-Raven Publishers; 1996. p. 687-700. 
23. Ferronato A, Landotti CT, Silveira RP. A incidência de alterações de equilíbrio estático da cintura escapular em crianças entre 7 e 14 anos. Rev. Movimento 1998;9:24-30.

24. Gross RH. The Pediatric Examination. In: Morrisy RT, Weinstein SL. Pediatric Orthopaedics. Philadelphia: Lippincott-Raven Publishers; 1996. p. 51-89.
25. Pini MC. Fisiologia Esportiva. Rio de Janeiro: Guanabara Koogan; 1978, Apud Bertoldi LF, Bianchi PC, Borges NP, Carrara E, Carvalho SM, Castellani TM, et al. Avaliação e orientação postural em escolares de 7-12 anos do Colégio Estadual Jardim Piza-Roseira. (Disponível). http://www.ccs.br/olhomagico/ peepin98/Gim16.html - Dezembro 2002).

26. Palastanga N, Field D, Soames R. Anatomia e Movimento Humano: Estrutura e Função. $3^{a}$ ed. São Paulo: Editora Manole; 2000. 